Researchers interviewed $211 \mathrm{crew}$ workers in orchard, vineyard and vegetable operations about their opinions of piece-rate pay versus hourly pay.

\title{
Crew workers split between hourly and piece-rate pay
}

\author{
Gregory Encina Billikopf
}

\begin{abstract}
When properly managed, piece-rate pay can result in enhanced wages for crew workers and increased productivity for growers. Despite the benefits of piece rate, crew workers were evenly divided between those who favor hourly pay and those who prefer piece-rate pay. Crew worker concern about how piece rates are determined played a key role in the unexpectedly low preference for piece rate. Suggestions are offered for establishing piece rates as pay incentives.
\end{abstract}

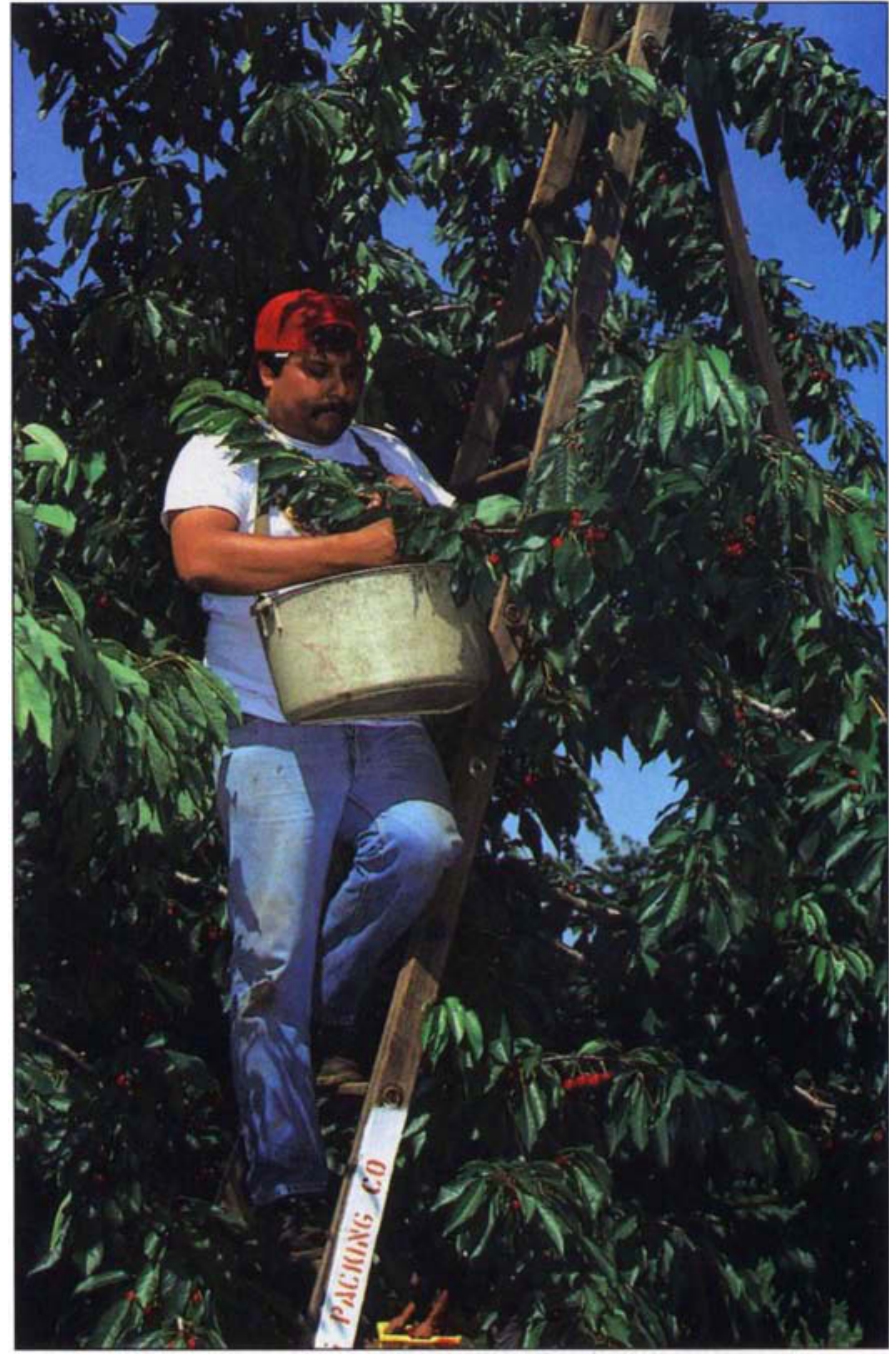

Piece-rate pay can result in enhanced wages for crew workers and increased productivity for growers. These gains are not always achieved, however. Many farm employers are concerned that quality suffers when workers are paid by the piece. Quality concerns can be overcome, but other challenges remain. Why is it, for instance, that some workers do not seem motivated by piece-rate work? What effect does worker attitude have on productivity?

Two separate studies were conducted in an attempt to find both grower and crew worker feelings about piece rate. In the first study (1992-1993), a survey instrument was used to collect data from 404 fruit, nut, grape and vegetable growers. In the second study (1995), 211 crew workers were interviewed in orchard, vineyard and vegetable operations. Grower feel- ings are briefly summarized, but the emphasis of this report is on crew worker responses.

\section{Grower responses}

Survey respondents included 160 fruit (and some nut), 157 vineyard and 87 vegetable growers. The grape growers were mostly California farmers; the other categories included growers from other states.

Sixty percent $(n=220)$ of the growers had used some sort of incentive pay and $40 \%(n=146)$ had not. Those who had used incentives ranked the following as their top 5 (out of 14) concerns when using incentives: (1) poor quality work, (2) no change in worker performance, (3) difficulty in setting standards, (4) change in work methods or technology and (5) neglect of important goals not directly rewarded.
Most incentives $(92 \%, \mathbf{n}=202)$ were geared to field workers. Sixty percent of the growers were very pleased with their incentives, $35 \%$ were somewhat pleased and $5 \%$ were not pleased. In turn, $61 \%$ of grower respondents felt that their employees were very pleased and 35\% thought employees were somewhat pleased, while $1 \%$ thought they were not pleased and $2 \%$ were indifferent.

\section{Crew worker responses}

Crew workers were involved in multiple jobs such as cutting, picking, sorting, sweeping and knocking for harvest, removing leaves, suckering, grafting, covering grafts, digging roots and planting posts. Farming operations included (from most to least frequent) grapes, bell peppers, almonds, peaches, watermelons, pumpkins, 
more.) Another lamented that conditions had gotten worse over the past 10 years.

Numerical data show that workers are split between a preference for hourly and piece-rate wages. Crew worker comments explaining their reasons for pay preferences are illuminating.

\section{Preference for piece-rate pay}

The most common reason for preferring piece-rate pay was increased earning potential. Workers could acquire greater earnings in fewer hours of work, even though it took more effort to do so. Workers also felt they could work at their own pace without being pressured. For one crew worker, piece-rate work was more exciting and less boring.

Crew workers reported that when they are paid by the hour, some supervisors constantly push for faster work, expecting piece-rate effort for hourly pay. The word carrilla (slang derived from the Spanish words carrera, race, and correr, run) was often employed to describe this pressure for faster work. Several workers drew examples from previous jobs: "Some expect that we don't even talk to other employees [when paid by the hour]," a worker explained. Another witnessed a young woman who was not permitted to go to the bathroom even though she was ill. The woman ended up vomiting in the field. Another worker who requested a break after hours of exertion was refused with the comment, "Why do you want a break? Chavez is dead."

\section{Preference for hourly pay}

Worker preference for hourly pay fell into three general categories, from most to least frequently mentioned: crew workers (1) felt that piece rate was unfair, (2) preferred the pace of hourly paid work or (3) associated other benefits with hourly pay.

Piece rate unfair. A worker's sentiment that employers want "piece-rate effort for hourly pay" takes on a different twist here. Workers are being paid on a piece rate, but may earn no more than when paid by the hour. Some felt that piece rate was a gamble, never knowing how it would pay. One worker felt that the added effort of piece-rate work should result in at least twice the hourly wage.

A worker described how on a previous job he had been offered $\$ 1$ per box of apricots picked. When he picked 100 boxes for the day the rate was suddenly changed to 50 cents per box. A common view was, "I would like piece rate, but only if more effort means more pay. What they have done here is pay us less per unit of work once they found out we did too much. They forget that we put much more effort into this work by the piece." Another worker explained, "If we are making too much on piece rate we are told to also weed and that reduces our earnings." Sometimes the change is not made during the season. "Four years ago I could really earn more money by the piece. The next year they reduced the rates. That is why piece rate is no good."

A crew worker was frustrated with agricultural employers who don't specify, up front, what the piece rate is. "They wait to see how the day comes out," he explained. These employers are thinking in terms of what they want to pay the average employee on an hourly basis. Workers soon realize that increased performance translates into lower rates per piece. This worker pleaded, "Tell them not to do that."

Another crew worker explained that being sent back to redo a job takes on more serious consequences when the worker is being paid by the piece. Workers felt that supervisors needed to appraise their task performance in a timely fashion.

Liked pace of hourly pay. Many of the crew workers who preferred hourly pay liked the calmer, easier pace of hourly work. One woman felt that piece-rate pay was more a man's work, but was quick to add that women who wanted to do piece work should be permitted to do so. Some of the older men said that they preferred

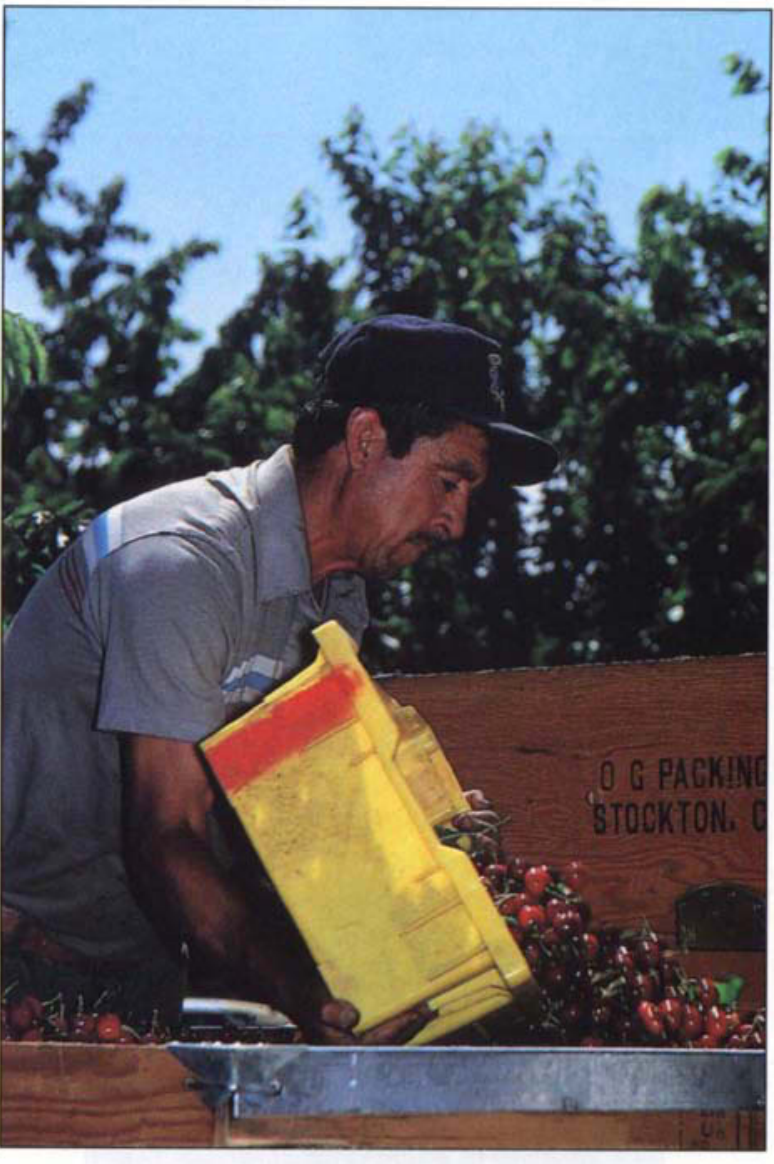

Some workers preferred hourly wages because they felt that piece rate was unfair, especially if the employer changed the rate after the job had begun.

piece rate when they were younger, but would now choose hourly work. One worker explained with pride, "I used to pick melons [at piece ratel for 14 years, but I don't do it anymore. It's very heavy work and now that I'm almost 30, I can't do it. I used to want to be the best in the crew and run around like a horse. It was a competition to see who would make more. Once we made $\$ 1,097$ each for the week. By 12 o'clock we would have made $\$ 100$ each, but would keep going. On good days, one could pick $\$ 10$ in 20 minutes."

A few crew workers felt that they were not fast enough to do piece-rate work. One employee attributed his preference for hourly pay to a bad back. A couple of workers mentioned getting breaks as a benefit of hourly work.

Hourly pay associated with other benefits. For a third, even smaller, group of employees, hourly pay was associated with other benefits, such as a longer work season and more hours 


\section{Recommendations}

Here are a few recommendations to farm employers who would like to consistently achieve higher worker motivation under piecerate pay:

- Think more in terms of how much it should cost to do a job, rather than how much to pay a worker per hour. In a properly constructed incentive pay system, the more the worker earns, the better off the employer is.

- Set standards carefully and inform workers ahead of time of the piece rate. Fair piece-rate formulas can be developed taking into consideration crop density and (where records exist) labor costs.

- Once a pay level is set, it should not be reduced.

- Provide training and performance appraisal early on when workers change from one task to another. Even better, crew workers should earn the right to work on piece rate when they have proven their full understanding of expected quality, and not before. - Add quality incentives to piecerate pay to reward employees who consistently achieve high quality. Additional training or discipline can be implemented when employees consistently perform below quality standards.

- Where weather and crop conditions permit, hire fewer workers so the working season can be extended.

- Encourage workers to take breaks. This may take some creativity, such as bringing in warm bread or cold sodas to workers.

- Make sure that workers are paid regularly.

- Consider offering health insurance for year-round employees, whether they are paid on an hourly or a piece rate basis.

- Where possible, provide hourly paid jobs for workers who prefer hourly pay over piece-rate pay. of work available, higher pay, a steady check rather than one paid at the end of the season and health insurance coverage. Further, some employees associated hourly work with growers and piece-rate pay with FLCs.

\section{Conclusions}

Crew workers in this study were evenly split between those who preferred hourly pay and those who preferred piece-rate pay, the most common incentive used with crew workers. This result seems at odds with a grower feeling that workers generally seem pleased with incentives. But it certainly helps explain why, after poor-quality work, the next two top concerns of growers who try to motivate employees through incentives are (1) seeing no change in worker performance and (2) difficulty in setting standards. These factors are closely related. Workers are hesitant to give their all when they fear that piece rates are not firm. "If I knew what I was being paid by the tree thinned, I would have already finished this row," a crew worker explained in an earlier study (California Agriculture, Jan-Feb 1995).

Farm employers have a challenge in setting fair rates when crop conditions are so variable from year to year. Employers who fail to do their homework in setting piece rates sometimes ask workers to go ahead and work for a piece rate that will be announced later, or have workers perform by the hour for a couple of days and then set the piece rate. In either case, workers soon learn that the faster they perform during these initial periods, the lower the pay for work performed.

At times, employers make a mistake in setting pay standards and end up paying more than they think they should. Some have reduced the piece rates at this point. In doing so they lose employees' trust and make workers hold back, fearful that superior performance will bring down their wages-if not immediately, maybe next season. Other employers set piece rates that are too low to begin with, so crew workers don't think the work is worth their effort.
The main reason workers prefer piece-rate pay is a desire to get the work done quicker and earn more. A secondary reason is to escape the nagging or carrilla that sometimes accompanies hourly work. Another negative practice of one grower was using "rabbits" - that is, paying a couple of workers under the table to work faster in an effort to get more out of an hourly crew without having to pay more.

The two main reasons that workers prefer hourly pay are to avoid the games associated with piece-rate pay and a preference for the slower-paced hourly working conditions. Laboring by the hour can be substantially calmer, and offers breaks. Although in theory piece-rate workers can take a break whenever they want, in practice workers often forgo their break because they are not compensated for break time. A third reason for preferring hourly pay is to obtain other benefits associated with hourly pay.

Worker differences accounted for some variance over a desire for piece rate versus hourly pay among crews. For instance, both gender and age had some effect on worker desire to work by the piece or by the hour. However, it is important not to generalize about either gender or age in terms of individual employee abilities. For instance, in an earlier study of vineyard pruners (California Agriculture, MarchApril 1988) a woman allowed her husband to surpass her in a pruning test, even though daily work records showed she was consistently the fastest pruner on the crew.

G. Encina Billikopf is Area Labor Management Farm Advisor, Stanislaus County, UC Cooperative Extension.

The portion of the study that focuses on grower perceptions was conducted with a grant from the UC Agricultural Personnel Management Program (APMP). Farm employers interested in a more comprehensive list of recommendations can write to the author at University of California, 733 County Center 3, Modesto, CA 95355; call (209) 525-6654; or e-mail gebillikopf@ucdavis.edu. 